CANADA. Canada-land cover associations. (National Atlas of Canada, 5th ed. - MCR 4113). Ottawa: Geographical Services Division, Energy, Mines and Resources Canada, 1989. Scale $1: 7,500,000$.

CANADA. Canada - native peoples, 1740. (National Atlas of Canada, 5th ed. - MCR 4094). Ottawa: Geographical Services Division, Energy, Mines and Resources Canada, 1988. Scale $1: 7,500,000$.

UNITED STATES. Electing the President, 1789-1988. (National Atlas sheet). Denver: U.S. Geological Survey, 1989. \$4.50.

MASSACHUSETTS. Metro Boston transit map. Taunton, MA: Arrow Publishing Co., 1989. \$1.95.

NEW YORK. Erie County. (New York Digial County Base Map Series). Albany: State Department of Transportation, 1990. Scale $1: 75,000$. $\$ 4.50$ or $\$ 6$ (Map Information Unit, State Department of Transportation, Office Campus, Building 4 - Room 105, Albany, NY 12232).

CALIFORNIA. AIDS in LA. Northridge: Center for Geographical Studies, 1989. \$5 (Center for Geographical Studies, California State University, Northridge, CA 91330),

CALIFORNIA. Calfiornia: land managed by the Bureau of Land Management and other federal agencies. Sacramento: Bureau of Land Management, 1989. Scale 1:750,000.

NORTH SEA. Tectonic map of the North Sea and adjacent onshore areas.Working: GECO Exploration Services, 1989.

GERMANY. The Berlin region. (Washington: Central Intelligence
Agency, 1989.) Scale 1:75,000.

SuDoc No. PrEx 3.10:B45/3.

ISRAEL. Gaza Strip, August 1988. (Washington: Central Intelligence Agency, 1989.) Scale 1:150,000.

SOVIET UNION. Soviet pipeline map. London, Ontario: Department of Geography, University of Western Ontario, 1989. \$27 (Order from Milford Green, Department of Geography, University of Western Ontario, Social Science Center, London, Ontario N6A 5C2.

AFRICA. North-Central Africa. (Washington: Central Intelligence Agency, 1989.) Scale 1:5,000,000.

ANTARCTICA. Oblique maps of Antarctica. (Miscellaneous Investigations Series I-1992). Denver: U.S. Geological Survey, 1989.

\section{NATIONAL ATLAS OF CANADA}

The ACML Bulletin No. 73 (December 1989) on Pages 11-17 provides an outline of published and proposed map titles for the National Atlas of Canada, 5th edition. Forty one maps remain to be published with the completion date by 1992 . Canada has produced more national atlases than any other country. The publication dates of the National Atlas of Canada are 1906, 1915, 1956, 1974, and 1985-

\section{new atlases}

Atlas of China. Chicago: Rand McNally \& Co., 1990. 48 p. ISBN $0-528-83385-5, \$ 8.95$

Attenborough, David. The Atlas of the Living World. Boston: H.M. Houghton Mifflin Co., 1989. ISBN 0-395-49481-8. \$39.95.
Barnaby, Frank (ed.). The Gaia Peace Atlas: Survival into the Third Millenium. New York: Doubleday, 1988. $271 \mathrm{p}$. ISBN: 0-385-24190-0. \$29.95.

Bayley, Christopher. Atlas of the British Empire. New York:

Facts on File, 1989. ISBN 0-81601995-9. $\$ 40$.

Census Canada 1986: Metropolitan Atlas Series. Ottawa: Statistics Canada, 1989. \$24 (Canada) \$25 (Other countries) $\$ 30, \$ 31 * /$ set $\$ 240$ and \$250 (Statistics Canada, Publication Sales, Ottawa K1A OT6). Clacary, Edmonton, Halifax, Hamilton, Montreal*, Ottawa-Hull, Regina, St. John's, Toronto*, Quebec, Vancouver, and Winnipeg.

Courbon, Paul. Atlas of the Great Caves of the World. St. Louis: Cave Books, 1989. 369 p. ISBN 0939748-21-5. \$25.

Friesel, Evyatar. Atlas of Modern Jewish History. Oxford: Oxford University Press, 1989. ISBN 0-19505393-1. \$39.95.

Harris, Geraldine. Atlas of Ancient Egypt. (Cultural Atlas for Young People Series). New York: Facts on File, 1990. ISBN 0-8160-1971-1. $\$ 17.95$

India Market Atlas. Hong Kong: Business International Asia/ Pacific, 1988. \$345 (Business International, 215 Park Avenue South, New York, NY 10003.

Keegan, John (ed.). The Times Atlas of the Second World War. New York: Harper \& Rowe, 1989. 256 p. ISBN 0-06-016178-7. \$45.

Lobel, Mary D. (ed.). Atlas of Historic Towns: London From Prehistoric Tmes to 1520. Oxford: Oxford University Press, 1989. ISBN 0-19-822979-8. \$110. 
Manley, John. Atlas of Prehistoric

Britain. New York: Oxford

University Press, 1989.

ISBN 0-19-520807-2. \$39.95

(Mainly photos and text).

Messenger, Charles. The Chronological Atlas of World War Two. New York: Macmillan Publishing Co., 1989. 255 p. ISBN 0-02-

584391-5.

Middleton, Nick. Atlas of Social Issues. New York: Facts on File, 1989. ISBN 0-81760-2024-8.

Milner-Gulland, Robin. Cultural Atlas of Russia and the Soviet Union. New York: Facts on File, 1990. ISBN 0-8160-2207-0. \$40.

NBC News: World News Atlas. Skokie, IL: Rand McNally \& Co., 1990. ISBN 0-528-83371-5. \$7.95.

Pope, Rex (ed.). Atlas of British Social and Economic History Since c. 1700. New York: Macmillan, 1989. ISBN 0-02-897341-0.

Price, David H. Atlas of World Cultures: A Geographical Guide to Ethnographc Literature. New York: Sage, 1989. 156 p. ISBN 0-80393240-5. \$35.

RAC Motoring Atlas Britain. London: George Philip, 1989. 128 p. 9th ed. ISBN 0-540-05551-4. L4.95.

Rand McNally Photographic World Atlas. Chicago: Rand McNally, 1989. 192 p. ISBN 0-528-83363-4. $\$ 34.95$.

Raza, Moonis. An Atlas of Tribal India: With Computed Tables of District-level Data and Its Geographical Interpretation. New Delhi: Concept Publishing Co., 1990. 461 p. ISBN 81-7022-286-9. $\$ 100$ (Available from D.K. Agencies (P) Ltd., H-12, Bali Nagar, New Delhi 110015).
Rigby, Philip. Atlas of Australia and the World. Port Melbourne, Vic.: Philip George \& Son, 1989. 144 p. ISBN 0-88665-488-2. \$59.95.

Sergeevam, S.I. (ed.). Atlas Mira. Moscow: G.U.G.K., 1988. 33 p. incl. 206 maps. Rbl. 9.26.

Smith, Richard M. The Atlas of Arkansas. Fayetteville: University of Arkansas, 1989. 226 p. ISBN 055728-047-9. \$30.

Times Atlas and Encyclopedia of the Sea. New York: Harper \& Row, 1989. 272 p. ISBN 0-06-016287-2. $\$ 59.95$.

United States Today: reproducible maps. Wellesley, MA: World Eagle, Inc., 1990. \$25.50 (paperback), $\$ 26,50$ (looseleaf), and $\$ 36.95$ (hardcover).

World Bank Atlas. Philadelphia: World Bank Publications, 1989. Order Stock \# 11354. \$5.95 (World Bank Publications, P.O. Box 7247 8619, Philadelphia, PA 191708619).

World Market Atlas. Hong Kong: Business International Asia/ Pacific, Ltd., 1989. 218 p. \$385.

\section{map library bulletin board}

This forum is offered to encourage communication among map librarians at a time of rapid technological transition. Questions, comments, and announcements are invited.

Electronic information is a reality in many of our map libraries. What fears, experiences, and/or expectations await the map librarian in the 1990's? Abstracts of two articles are presented here to initiate this column. The first challenges us to think about the potential use of electronic information in the map library; the second describes one map libraries experience of establishing a public access computer-assisted mapping program.

North, Gary W. (1989). Will your library be the spatial data information center of the future? Inspel: Official Organ of the IFLA Division of Special Libraires, 23:2, pp. 130-136.

Abstract: In the earliest days of recorded civilization, people pressed square-ended styluses into wet clay to record information. Today they press square keys on a computer keyboard. Vast amounts of data about the Earth and man's activities are being entered into digital spatial data bases. These data have been structured so that they are described in terms of their exact geopraphic position on the Earth. The data, in the form of points, lines, or polygons, can describe geology, soils, water, forest cover, or population statistics. To use these data, geographic information systems (GIS's) are being developed to collect, inventory manage, analyze, and display the spatially referenced data sets. These systems will handle both raster (grid cell) or vector (line segment) data and allow the use of knowledge-based software to emulate the problem-solving process of the human brain. By having access to spatial data and the accompanying GIS and knowledge-based software, librarians will be able to expand their reference services. Because the library has been the center for published information through time and is the one place where all disciplines can truly live together, people will expect to find spatial data there also. The biggest problem in establishing this type of library system may be in just getting the approval to start. Because the data and the systems are now available is there any 